\title{
'And So He Died as He Had Lived, in Exile and Alone': Friendship, Narrative and the Politics of Remembering
}

\section{CHRISTOPHER BURKE}

Friends were quick to mark the passing of New Zealand novelist James Courage when he died in London in 1963. Courage (1903-63) had found popular and critical acclaim in Britain and elsewhere. This was an accomplishment that few others of his generation had matched. Still fewer, perhaps only Takapuna-based writer Frank Sargeson, could claim to have the attained even a modicum of his success internationally. All of Courage's novels had been published in England. A good many had also been printed in the United States and Europe. Courage's friends implied, however, that this success - eight novels in three decades - not to mention numerous short stories, poems and a London-based play - had been bought at great personal cost. Courage had died just two years after his homosexual novel, A Way of Love, was withdrawn from circulation in New Zealand. Courage's friends suggested he had died in exile: without friends, without even a place in the world. As friend and fellow writer, Phillip Wilson stated, Courage had 'died as he had lived, in exile and alone'. ${ }^{1}$

The narrative of 'Courage as exile' had little bearing on the reality of his lived experience. Courage was not an 'expatriate' in these reminiscences, a term which implies at least some semblance of personal agency. Rather, Courage's status as a homosexual combined with - and also reinforced - assertions about New Zealand's purported puritanism. Wilson wrote, for example, how Courage's 'roots' were in New Zealand, and that the Antipodes continued to be the source of the writer's creativity and imagination. This explained the older man's melancholy when the pair met at a gathering of artists in London in the late 1950s. Writing in Landfall in 1964 Wilson recalled a figure who had been marked by an 'air of isolation and loneliness'. ${ }^{2}$ A 'stimulating talker', Courage had nevertheless proved to be 'reserved to the point of reticence about his private life'. ${ }^{3}$ Wilson believed that the banning of his homosexual novel had been a 'blow to a man so sensitive'. ${ }^{4}$ Indeed, Wilson concluded upon reflection, that this experience had surely confirmed for Courage the 'puritan narrowness' of New Zealand, a 'hardness and rawness' that would forever exclude 'his outlook on life'. 5

This kind of narrative framework proposed a trajectory that was at once fictive and historically attuned to a precise cultural moment. This essay looks first to this ad hoc programme of memorialization, and then to an analysis of Courage's own social relations as he understood them. I show that articulations about Courage's life were not innocent of discourse and ideology. Indeed, they intersected with - and helped to produce - changing ideas about artistic and sexual identities in New Zealand after $1963{ }^{6}$

Narratives about Courage - of which Wilson's is perhaps the best known - were continually nourished and reinforced by the literary trope of the Man Alone. Here, however, this literary device is given slightly queer - and queering - capacities. Male homosexuality is mobilized in these accounts as a source of trauma and alienation. These meanings elide the homosocial connectedness that had persisted since Victorian times and borrow instead from the newer language of medicine to express a knowable - if compassionate view - of male homosexuality. ${ }^{7}$ Here Courage becomes a vehicle for establishing the essential inhumanity of New Zealand's colonial enterprise: a reality that confirmed for many how those with non-normative identities were excluded from public life, both spatially and otherwise. 
Courage's own voice, in the form of his letters, journals and published literary material, very quickly calls into question these historical assumptions. In particular, this essay examines Courage's ongoing affiliation with New Zealand and New Zealanders. National identity remained a central vector of sociability and interaction throughout Courage's life course, one that was continually revitalized by London's imperial and cultural connectedness. Far from being an 'exile', Courage's location at the very centre of the British world provided rich opportunities for his immersion in a community of expatriate New Zealanders that resided at the capital. Having established himself within the queer and literary strata of the city, Courage also played an integral role in facilitating other New Zealanders' entrance into London's wider artistic and queer networks.

This article draws from my work on critical biography and cultural history. There I explore the 'process of invention' that homosexuals used to fashion 'coherent' identities in the years before liberation (1972 in New Zealand). ${ }^{8}$ I argue that Courage's identity constructions give substantive clarity to one man's subjective vision of the world. His testimony - particularly that taken from his unpublished journals and correspondence provide manifold insights into his material realities. While sometimes Courage's experiences were far from happy - he struggled with mental illness for much of his life his voice continually emphasizes the remarkable tenaciousness of the queer and professional bonds that characterized his social milieu. Clarifying some of these linkages brings new perspectives to issues long obscured; it also sheds light on how preliberation lives were lived by those who experienced them.

\section{Remembering James}

James Courage arrived in the London near the end of the European summer in 1923. He took up a Bachelor of Arts in English at St. John's College at Oxford University, and completed a migration to the British centre that, as a nineteen year old, would have seemed fitting for a man of his class, age and temperament. ${ }^{9}$ Staying first with relations in Dorchester, Courage went by train to the capital some weeks later. His delight upon reaching his destination was palpable. 'Can't you imagine the London streets at dusk', James wrote in his journal on the 23 September. ${ }^{10}$ The city, 'full of lights and hurrying people and men in the gutters' suggested a frenetic energy that was uniquely metropolitan. ${ }^{11}$ Here were 'the lighted signs of Piccadilly Circus', the 'glowing theatres' of the West End, and a scene of bustling cultural life. ${ }^{12}$ It seemed both overwhelming and somehow life-affirming to the young New Zealander: '[I]magine ... somebody flying past in an opera hat and just around the corner coming on a beggar, one side of his face a great red scar, drawing with coloured chalks on the pavement the illuminated words "To Live"". 13

Courage had begun to think of himself as a writer of New Zealand fiction as early as the 1930s. In doing so, he tapped into the drive for an authentically New Zealand 'voice' which was then emerging as an aspiration amongst local New Zealand writers and artists. ${ }^{14}$ On 4 September 1931, for example, Courage wrote of his reaction upon reading the London Mercury's letter on New Zealand writing. Courage heard how critics were 'scanning the landscape' for a writer of note but had so far found no one of note. Katherine Mansfield had dominated the short story, but what of the great New Zealand novel? 'I have more than a good mind to have a shot at that novel myself', Courage wrote, 'if I can think of a fine subject'. ${ }^{15}$ Courage finally succeeded in publishing his first novel, One House, two years later, whilst recovering from tuberculosis at Mundesley, Norfolk. This was not a New Zealand story, however, but a narrative of emphatically British mood and focus.

While Courage wrote of his dual heritage - British and Antipodean - it was in his New Zealand writing that he found his greatest success. Of his eight novels, five were set in 
New Zealand - for the most part, the gentrified landscape of his Canterbury childhood. Courage's inclusion within an emerging critical literature on New Zealand writing helped shape his identity as a writer of local fiction. Periodicals like Landfall and the New Zealand Quarterly signaled for Courage his own position within an emerging cohort of intellectual pioneers. Indeed, he felt that these productions would have a place in 'any future history' of national culture. ${ }^{16}$ With three New Zealand novels in print by the early 1950s and a number of short stories about to be published in Landfall, Courage considered himself firmly at home in writing stories of a distinctly New Zealand slant and perspective: '[W]hy do I go on writing? One reason is that I believe I've written about people in Canterbury (N.Z.) as it has never been done before - just as [Ivan] Turgenev wrote about certain people in Russian provincial society as it had not been done before'. ${ }^{17}$

Courage's feelings were not without validity. His New Zealand stories had by this time garnered considerable acclaim, both in Britain and New Zealand. In 1955, Courage had been declared by the Christchurch Press as 'the greatest living New Zealand writer' after his The Young Have Secrets (1954) was named a Book Society's Book of the Month selection in England. ${ }^{18}$ Courage had based the story on his adolescent memories of Sumner, where he had been a boarder of Clement Lester Wiggins - his headmaster at Dunelm Preparatory School, Christchurch, from 1912 to $1915 .{ }^{19}$ The novel sold in excess of 100,000 copies internationally, making it one of the most successful New Zealand stories in recent memory. This was a wholly different style of writing than that practised by friend and fellow-writer Frank Sargeson; Courage's fans wrote of the London-based author's 'delicacy and understanding'. ${ }^{20}$ By the mid-1950s Courage had achieve a respected, if modest literary reputation, and was considered by many to be a writer of 'sensitivity' and skill. ${ }^{21}$

Courage's fiction continually featured queer themes and characters. At times, these plot elements were encoded as stories of homosexual experience that only 'outed' themselves to those audiences capable of detecting their queer underside. ${ }^{22}$ Other narratives, Fires in the Distance (1952), for example, or the short stories 'Guest at the Wedding' (1953) and 'Scusi' (1954), feature explicit depictions of homosexuality, but in muted tones. (These protagonists typically possess deep-seated psychological impediments that prevent their full sexual awareness for much the story.) Thus, A Way of Love (1959) was in many respects a departure. Courage had wanted the story to be set in the New Zealand but feared that that narrative already risked alienating New Zealand's supposedly much less cosmopolitan audience. ${ }^{23}$ Even so, these are explicitly homosexual figures who, as one character asserts, are 'no strangers to the land of Sodom'. ${ }^{24}$ While Courage was careful to assert the respectability and rectitude of his protagonist, the novel was in the final instance one of quiet protest, one that sought to elicit the sympathies of a predominantly heterosexual audience for the plight of homosexuals.

The reception of A Way of Love in New Zealand, occurring as it did near the end of Courage's career, had a profound impact on the way in which he was remembered. With the exception of a lengthy memorial in Landfall, which remained staunchly supportive of one of its more prominent and long-time contributors, Courage very quickly slipped from New Zealand's national and collective consciousness. Courage had taken considerable comfort from the great many fan letters he received from strangers, many of whom were homosexual. ${ }^{25}$ Even so, critics in New Zealand were much less supportive of the novel. ${ }^{26}$ Beginning with its censorship in 1961, a curious and rather implacable reversal of fortune was set in motion. By connecting Courage to 'indecent' - even 'pornographic' - literature (as some had called A Way of Love), his detractors brought his professional and personal integrity into disrepute. ${ }^{27}$ Christ's College in Christchurch, where Courage had been schooled as a teenager, quietly distanced itself from its former pupil. ${ }^{28}$ And all of 
Courage's novels - not just A Way of Love - were withdrawn from circulation in some of New Zealand's public libraries. ${ }^{29}$

While Courage had gone from being a celebrated literary hero to a denigrated social pariah in little over three years, this cultural reaction reverberated throughout New Zealand's queer and literary community. Indeed, it was some twenty years later, in 1983 when Gay Men's Press published Barry Nonweiler's That Other Realm of Freedom - that anything quite so explicit was attempted by a New Zealand writer. ${ }^{30}$ Only some years later, in the context of gay liberation, did Courage's work - and indeed his own life story return to prominence. ${ }^{31}$ Here Courage was placed centre stage in activists' attempts to 'recuperate' a queer national imaginary that many felt had been actively suppressed by New Zealand's inexorable pattern of homophobia and gender conformity. These re-tellings combined the notion of 'Courage in exile' that emerged immediately after his death, and affirmed a sexual minority that sought to recuperate and reaffirm past homosexual forebears.

The dynamic nature of memory and memorialization has been well rehearsed by cultural historians who point to how 'conflict and contest' converge to produce accounts of the past. ${ }^{32}$ These negotiations, Katharine Hodgkin and Susannah Radstone suggest, occur because memory is always 'alive and active'. ${ }^{33}$ Memory, they argue, is 'charged with the weight of [historical] contest'; it is always attuned to the different 'strategic, political, and ethical consequences' that flow from particular versions of stories. ${ }^{34}$ The way that Courage's life narrative is reworked by activists and other liberals bears out the proposition that memory 'reshapes, [and] attempts to comfort' the 'changing needs' of contemporary subjects. ${ }^{35}$ These very selective narratives - one's that continually stressed Courage's marginalization as a 'gay man' (a term he seldom used, and never to describe himself) were also used by activists to press home the importance of their current political struggles. Courage's story made tangible the vagaries of New Zealand's puritanical past. It also confirmed for liberationists the pressing need for a viable 'gay society' in the present.

By far the more complex of these interpretations was Bobby Pickering's 'The Conspiracy Against James Courage', which appeared in Pink Triangle in December of 1980. This article, and others like it, point to the curious afterlife that Courage enjoyed in the narrative retellings of New Zealand's most recent past. They also illustrate how certain narratives of sexual dissidence - Oscar Wilde's is perhaps the best known internationally are reused and reinvigorated under changing political and cultural circumstances. ${ }^{36}$ Courage's 'sexuality', rather than, say, his class or cultural background, was used by contemporary narrators to explain his migration from New Zealand. Courage was an 'exile from an insular puritan world', Pickering wrote. ${ }^{37}$ This was a sensibility necessarily informed by the 'sexism and merciless imperialism of straight white males', who, he argues, opposed - sometimes violently - any variation of the masculine status quo. ${ }^{38}$ This was a ruthless hegemonic force that Pickering asserted existed at every level of society, including the literary.

By looking to Courage's treatment at the hands of the nation's literary critics, Pickering determined that the writer had been brutalized by New Zealand's 'literary mafia'. ${ }^{39}$ This suggested an organized regime replete with oppressive - even thuggish tendencies. Courage's treatment was explicable historically since New Zealand's inherent homophobia was also matched by its literature. This was a cultural output that, Pickering suggests, continual reinforced the 'good keen man' at the expense of a much wider reflection of its national masculinities. ${ }^{40}$ Preliberation homosexuality was presumed to be a bleak and repressive reality, and any break in the 'homogeneity' of New Zealand's masculine self-representation was subject to the 'blind bigotry' of a virulent and deeply puritan literary elite. ${ }^{41}$ Just as it is only became possible to be 'gay' in 1972, so too, 
Pickering wrote, was greater literary freedom only available to those who toiled in the latter part of twentieth-century. While writers like Pickering hoped to revive interest in Courage, his life-story was invariably a vehicle for a much wider social critique:

It saddens me that having rejected the political fascism of the New Zealand literary scene, Courage should immediately lose his way in the personal politics of sexuality. He never questions the family structure in A Way of Love, he fails to challenge the processes of psychiatry [in The Visit to Penmorten]. Reading these books makes me aware of how much I owe gay liberation, for I have been bequeathed the insights of a dialectical analysis of my personal oppression. And it angers me that a fellow gay was denied these insights. The conspiracy against Courage's reputation was appalling, but the conspiracy against his homosexuality should be concern of every gay person. ${ }^{42}$

Liberationist discourses were not solely taken up by avowedly gay activists. Rather, they formed cultural investments across political and sexual spectrums. Writing for New Zealand Listener in 1982, for example, David Young wrote about Courage's experience in an article called 'Courage in Exile'. ${ }^{43}$ Even so, Courage remained central to gay assertions about the New Zealand's social conservatism well into the 1990s. For instance, writing ten years after New Zealand's homosexual law reform, Peter Wells suggested that gay men and lesbians were still being actively kept from their homosexual heritage. Wells and poet Rex Pilgrim had sought to include Courage in Best Mates, New Zealand's first anthology of gay fiction. However, their enthusiasm was met with disappointment when Patricia Fanshawe, Courage's sister and literary executor, would not allow them to use his stories. Courage's writings are the forced 'numbness of absences' that Wells refers to in his critical introduction; a lack that was doubly-felt since, as Wells argues, Courage's stories were the first to break the bleakness and silence instilled by New Zealand's homophobia. ${ }^{44}$

Wells's introduction represents the critical highpoint of liberationist narratives about Courage. Here Courage's life narrative becomes a kind of cultural shorthand. It represents in fairly stark terms the homophobia and oppression assumed to have formed the reality of 'preliberation' life in New Zealand. Indeed, New Zealand, Well suggests, remained 'frighteningly provincial' during Courage's lifetime. ${ }^{45}$ Wells writes that A Way of Love was a 'rather beautiful fish' that glittered 'for a moment in the sunlight' before 'submerging again' into the 'murky depths' of New Zealand's endemic puritanism. ${ }^{46}$ For contemporary writers like Wells, it followed that gatekeepers (Fanshawe and others) were critical in maintaining this repressive regime well into the present. These figures ensured that - even in death - men like Courage remained oppressed, being 'nurtured into a deeper silence' and repression that contemporary gays and lesbians would no longer tolerate. ${ }^{47}$

\section{Friendship and belonging}

I do not wish to dismiss these recuperative efforts, or to suggest that such accounts have not produced productive insights into New Zealand's queer past. Indeed, without these interventions it is likely that many such stories of sexual otherness - Courage's included might never have been restored to public memory. Wells and Pickering were not altogether incorrect in their views about Courage's life. Courage suffered greatly from various physical ailments, and he battled serious depressive illness from the late 1940s onwards. His stories - mostly autobiographical - had already caused significant ructions - legal and family-based - long before the publication of A Way of Love in $1959 .{ }^{48}$ What is more, Courage was never entirely comfortable with his own life in London, or indeed with his career as a professional writer (though, interestingly, he resisted the gradual pathologizing 
of homosexual identities that was evident amongst the medical fraternity of the 1950s and 1960s).

Even so, both Wells and Pickering wrote from liberationist contexts which filtered Courage's life history in significant ways, and both gave only a sparing glance to the actuality of his lived-experience. Liberationist approaches to the past have favoured a particular - and problematic - historical trajectory. The drive to 'rescue' and 'recuperate' men and women thought to be homosexual has often paid little attention to questions of subjectivity - or, for that matter, the complexities of how past sexual identities were produced. While even recent histories - Michael King's Frank Sargeson: A Life (1995) or Paul Millar's No Fretful Sleeper (2010) especially - have successfully mined sources thought to be impervious to queer interventions, their continued assertions about genealogical connectedness have played down difference between historical actors. These histories typically view sexual object choice as the sole and universal signifier of sexual otherness. They presume trajectories of progress, and mobilize illusory sameness as a means for claiming a collective unity based on a shared 'gay identity'. 49

Of course, the obstruction of other social agents - Fanshawe, in particular, but also Courage's publishers in London - meant that his personal history was kept under careful wraps after his death. Courage's journals, which he began writing from 16 years of age, give an impressive and much more fulsome insight into his life, and indeed the experience of the preliberation worlds of Britain and New Zealand. These were held at Hocken Collections, in Dunedin, from the late 1960s but remained under embargo until 2005, when members of the public were able to access Courage's private archive for the first time. With these reservations in mind, Courage's own life narrative shows the degree to which he was participant in various social networks, both metropolitan and peripheral, queer and square.

Courage's move to Europe did not extinguish his ties to New Zealand. While residing in London, Courage continually came into contact with other New Zealanders. For instance, he reported being one of several colonials - New Zealanders included - studying at Oxford University in $1923{ }^{50}$ Courage did not identify these men or explicate the nature of their intimacies at the time. However, in reminiscences recorded later, Courage himself makes it clear that his time at Oxford was a pleasant one. He found academic and artistic success there. ${ }^{51}$ At the same time, Courage also discovered a spirit of (mostly male) camaraderie that stood in marked contrast to the 'horrors' of his education in New Zealand. ${ }^{52}$

In some ways, Courage's network of friends may have been at its most heterogeneous during his Oxford years. Most of his friends, if not all of them, were either native Britons, or from a host of other (mostly) Commonwealth nations. It was only after moving to London in the late 1920s that Courage finally connected with the New Zealand expatriate community that already resided in the city. While for the most part Courage's compatriots were artists, or at least of an artistic persuasion, an analysis of his journals and written correspondence shows that this network was composed of both men and women, queer and, at least as far as Courage could tell, non-queer. This pattern of relations points to nationality - alongside sexuality and profession - as a primary point of social relation; and one (as I suggest below) that existed with surprising uniformity throughout his time in the Northern Hemisphere.

Courage records his attendance at several events with other New Zealand artists. In one letter written to New Zealand academic and pianist Frederick Page in 1940, Courage mentioned his presence at a 'general N.Z. concert' with poet and playwright D'Arcy Cresswell. ${ }^{53}$ This event was organized by New Zealanders, and attracted a large expatriate audience. Courage explained how a number of his New Zealand friends - Sir Hugh 
Walpole (English but born in New Zealand), Hector Bolitho, Shale Gardiner, Ormond Wilson and others - had 'been roped in' for the occasion. ${ }^{54}$ The evening opened with an impressive overture ('written specially') by composer Douglas Lilburn; this was followed by a speech by Walpole. ${ }^{55}$ Courage described the rest of the evening as being of 'mixed fare': a 'quite inaudible speech' by dramatist Merton Hodge, four 'good' cartoons drawn by political satirist David Low, and 'a couple of Chopin Etudes' performed by a young unnamed New Zealand pianist with a 'truly amazing' technique. ${ }^{56}$

The evening ended in comic disarray, however, when a cohort of older New Zealanders took control of the proceedings:

[S]everal very odd things began to happen: the old brigade began to take over. Rosina Buckman appeared in a sort of nightgown and panted a few words of apology for not being able to sing: Shayle Gardner appeared looking grave, and fired off Othello's defence at us: Stella Murry appeared in a crimson dress, carrying a bouquet of roses that looked as though they had died of fright and sang some wildlyinappropriate religious song. ... But the real climax of embarrassment was reached when a troop of (presumably) soldiers, in Maori undress, gave a haka: their leader ... sprang about the stage with such vim that the grass-skirt that he was wearing suddenly slipped completely off ... God alone knows what the Duchess of Kent, who was sitting in a box quite close to us, thought of it all! ${ }^{57}$

Comic (and painful) though it was - Courage records how he and D'Arcy were in a 'state of coma with suppressed laughter' for much of the proceedings - Courage usefully indicates how such events brought together a large swathe of New Zealanders who lived in London. National identity (and profession) was quite clearly the primary affiliation of those assembled. Certainly, the presence of the Duchess of Kent, the type of entertainment (classical music especially), even the venue (His Majesty's Theatre in Haymarket) signal a wider British ethos. ${ }^{58}$ Overall, however, such occasions provided a means for renewing national affiliation for New Zealanders who, like Courage, were removed from the geographic spaces of home. Such events cemented connections between social intimates and, in this case at least, helped offset some of the more deleterious effects of war.

The metropolis provided an array of spaces for such gatherings. Along with cultural exhibitions, New Zealand films and other civic events, Courage found numerous opportunities to participate in various rituals of nationhood that occurred within the metropolis. ${ }^{59}$ Of course, these events were held only occasionally, and the ability to converse at length in these spaces must have been constrained by social etiquette and other conventions of spectatorship. Intimate gatherings held at the homes of various friends, however, provided opportunities for far more regular (and informal) interaction. These occasions were almost exclusively composed of New Zealanders with literary leanings, along with their families (if indeed they had any). Invitations were seldom extended to those of other communities, further exemplifying the importance of profession and nationality as a shared vector of community formation and personhood within the metropolis.

After one such New Zealand gathering, Courage wrote to Charles Brasch (then residing in Dunedin) about an exceptionally enjoyable afternoon spent in the company of New Zealanders Bill Pearson, Maurice Duggan and poet and close friend Basil Dowling. ${ }^{60}$ The gathering had garnered Courage's comment because of the notable inclusion of an outsider, the Australian playwright Florence James. ${ }^{61}$ A 'good-looking pink-faced woman of about 45', Courage was clearly taken with her. ${ }^{62} \mathrm{He}$ wrote that he had been 'quite delighted' by her charm and hospitality. ${ }^{63}$ 
The wider narration of this event, and the many others that Courage recorded, point to how these episodes functioned as bastions of professional intimacy. This does not mean to say that these gatherings were not of a personal nature, or solely literary in their focus. Courage explained to Brasch how he and Florence had spoken at length about music. He also reveals intimate knowledge about Florence's domestic affairs which she had shared with Courage (the pair spent considerable time talking about their respective families). ${ }^{64}$ Besides offering good cheer and conviviality though, these gatherings were necessary outlets of professional exchange. Courage mentioned how this particular get-together provided an opportunity to hear the latest news from home, for example. He was also able to glance over the most recent edition of New Zealand literary periodical Landfall. ${ }^{65}$

Such interactions were not necessarily anchored to particular spaces. Courage's personal narrative suggests how he also met with individual members of this literary circle outside of these gatherings. In one letter to Brasch, for example, Courage mentioned how he had talked with Bill Pearson and Basil Dowling 'over iced beers' a few nights before; he also wrote of having spent apparently congenial time in the company of short fiction writer Maurice Duggan. ${ }^{66}$ For the most part, however, larger meetings of New Zealanders held special and enduring significance for Courage and other expatriate artists. In particular, they performed a key role in maintaining group cohesion and professional affiliation. Courage's encounter with Florence shows how these spaces provided expansive opportunities for contemporaries to meet, exchange news and familiarize themselves with literary developments in New Zealand.

Aside from two periods when he left London - one in Argentina in 1931, the other in New Zealand from 1933 to 1935 - Courage's insertion within this group was practically unbroken from the moment he established himself in the metropolis. Of course, networks and connections overlapped, and Courage belonged to other literary (and artistic) sets as well. His theatrical connections provided special privileges and unparalleled access to dramatic and queer spaces within the metropolis, for example. Two of Courage's plays were performed at Oxford. His queer-themed Private History, a play about a male-male boarding-school romance, was also performed at the Gate Theatre, in London, in 1938. Even so, an analysis of Courage's private material indicates a particular intensification of national and artistic affiliations over time. More than this, however, these forums also facilitated the entry of new members into the cohort, and through this, the wider networks of interaction and exchange that already existed in the city. ${ }^{67}$

Courage was a social lynchpin for many New Zealanders visiting London - short and long-term migrants alike. ${ }^{68}$ I borrow this terminology and set of ideas from social network theory in sociology. These scholars suggest that social networks are structures that consist of individuals who constitute 'nodes' (individual actors) and 'ties' (links and connections between social actors). They suggest how social actors may belong to multiple social networks and acquire significant positions within these vectors of interaction and exchange. Social network theory offers a productive reading of Courage's social relations, and shows how, overtime, he acquired increasing primacy in both expatriate and queer communities. James was a powerful acquaintance because he occupied a key position in multiple networks - queer and artistic, national and international. This was particularly the case for Courage's younger and New Zealand-born acquaintances who were typically less socially connected (particularly in the centre), or who sought access to social networks that would otherwise have been outside of their everyday purview.

For example, Courage took interest in the young composer Douglas Lilburn when he arrived in London to study at the Royal College of Music in 1937. Courage found the famously reserved Lilburn to be a 'nice reticent lad', but possessed of rare artistic taste and refinement. ${ }^{69}$ Writing to Page on the 14 April 1940, Courage described Lilburn as a 'very 
shy, rather inhibited person', but 'most charming' upon 'closer acquaintance' ${ }^{70}$ Lilburn had already become a fixture in Courage's life by this time. Writing in his journal just months earlier, Courage recorded how he had made a special point of attending Lilburn's Phantasy Quartet at the Royal College of Music earlier that year. (Here he noted some 'fine and delicate string-writing', but privately stated the performance to be somewhat 'lacking in vitality'.) Lilburn had also been to the older man's flat several times. The pair exchanged pleasantries, and Lilburn took the opportunity to play Courage's Bösendorfer. ${ }^{71}$

Through Courage, Lilburn had the opportunity to meet the men and women who frequented the New Zealand writer's residence, including professionals at the British Broadcasting Company. Lilburn would eventually have several works played by the British network. ${ }^{72}$ Having maintained his connections to New Zealand, Courage also encouraged Lilburn to correspond with various other New Zealand friends. Writing to Brasch, for example, Courage explained that Lilburn had been 'deeply interested in all the N.Z. musical news' he provided in one recent letter. ${ }^{73}$ Given their respective interests - Brasch was himself an avid musical buff - Courage believed both would benefit from a closer acquaintance. He encouraged Lilburn to write to the New Zealand poet at once. ${ }^{74}$

In 1952, Courage exclaimed to Brasch over the sheer number of 'N.Z. writers' he knew personally in London and saw on a regular basis. ${ }^{75}$ As I have already indicated, the 1950s marked the highpoint of Courage's literary career. But this was also when Courage was at his most active in assisting many New Zealanders - younger men especially - with their entry into the urban spaces and rhythms of the cultural centre. This was particularly so as Courage aged, and suggests the tangible ways that his contributions to expatriate networks may have shifted and deepened over time.

Courage wrote to Rodney Kennedy in early 1956, for example, having heard from another New Zealander - the historian Eric McCormick - of Kennedy's purported unease with London:

I have just had a letter from Eric McCormick in which he mentions that you are still in London, gives me your address and remarks that you are finding London pretty grim and cold after New Zealand. I must explain - before I go further - that I am a friend of Charles Brasch (you may have heard him mention me by name) and that I am living more or less permanently in Hampstead. The point is - would you care to come here and look me up some time ${ }^{76}$

Queer and artistic credentials were mobilized to remarkably good effect. Courage consciously situated himself within the network of queer intellectuals that Kennedy (himself homosexual) was already intimate with - historian Eric McCormick and poet, arts patron, and (then) editor of Landfall Charles Brasch. Courage's overture is carefully constructed and further premised on Kennedy and Courage's joint allegiance to a shared national culture and set of interests: 'I don't know how long you mean to remain in England ... but I should be glad to see you and to talk about New Zealand - not to mention the theatre, in which I believe you are interested'. ${ }^{77}$

It is clear that Courage drew a great deal of personal satisfaction from these associations. As I have noted, this was particularly so in Courage's later years. ${ }^{78}$ Courage's New Zealand friends formed an indispensable part of his social world - and not solely in professional terms. Basil Dowling and Charles Brasch, especially, were particular sources of confidence and emotional support. Dowling and Courage never lived far from one another from the time the former had moved to London with his family in the early 1930s. Both, however, maintained a robust written correspondence that augmented their (usually 
at least weekly) meetings; and Courage dedicated The Young Have Secrets to Basil in 1954 ('To Basil Dowling/ poet and friend/ for recollections in common'). ${ }^{79}$

This was no ordinary relationship. Courage stayed with the Dowlings after one severe mental breakdown in the mid-1950s, and again after Courage suffered the first of two heart attacks that would end his life in 1963. Courage wrote of Basil and his family as a 'warm and tender people', and had a particular fondness for Basil's wife Margaret. ${ }^{80}$ These episodes reveal much about Courage's material welfare; they also suggest how some New Zealand intimacies were not simply outlets for professional and personal pleasure. Rather, they were very necessary sources of physical and psychological care that at times verged on the familial.

Courage's sister, Patricia Fanshawe, resided in nearby Surrey, and James was not without other family connections in England. His father, after all, was British-born. ${ }^{81}$ Even so, Courage preferred to spend most Christmases with the Dowlings (as well as fellow authors, the sisters Lettice and Barbara Cooper, who lived nearby). Courage felt as though he was one of the family, and wrote that he was never shielded from domestic tensions in the Dowling household simply because he was a guest. Courage recorded one Christmas where 'a few underlying feuds started seeping through' once the 'harmonious' effects of wine wore thin, for example. ${ }^{82}$

Other get-togethers, like those Courage recorded one summer in 1961, provided a very necessary respite from Courage's mental anguish:

I went over to Highgate yesterday (Whit Monday) to see Basil and Margaret. The afternoon was England's brightest and freshest, so we had tea on the daisied grass in the garden, among poppies and lupins. Basil looked pale and tired, poor man, but Margaret was brown after a week in Cornwall (Newlyn). We all sat on deck chairs and ate chocolate cake and sandwiches; like a N.Z. picnic rather (I hoped the tea would taste of manuka-smoke, but alas the flavour was Highgate Grocer instead). I had been in one of my very worst depressions - my bane - but I managed to cheer up and talk. We spoke of you [Brasch], wishing you were with us in the hot weather (Dunedin's harbour must be full of pack-ice at the moment). ${ }^{83}$

National identity is quite clearly the focus of social interactions and intimacies here. Courage recalls how these occasions were given their New Zealand flavour by their leisurely and outdoor informality. The careful etiquette of the dining table is replaced by an ease Courage associated with New Zealand; and it was common for conversation to turn to matters of home. Courage wrote to Page in 1955 how at the Dowlings he enjoyed 'enormous bouts and tipples of New Zealand news and recollections'. ${ }^{84}$ These encounters were important events in the routine of Courage's domestic life and, when he felt able to face social interaction, one that frequently left him pleasantly 'mute from exhaustion' ${ }^{85}$

Along with Dowling, Courage was frequently in contact with Brasch, whom Courage had first met while visiting New Zealand in 1933. The pair saw each other regularly when Brasch was in England (particularly during World War Two) and both men remained in near constant contact by letter, as well the occasional postcard or telegram. Along with Frank Sargeson, Brasch was one of Courage's most prolific long distance correspondents and a figure whose friendship once again blended the personal and the professional. Like the Dowlings, both Brasch and Sargeson took an active interest in Courage's welfare. Writing to Sargeson, Brasch wrote of his constant concern for the English-based writer, stating in 1955 that there seemed a 'great deal of pain and uncertainty in [Courage's] letters'. ${ }^{86}$ While Courage had survived his most recent bout of mental anxiety, Brasch 
(rightly) suspected that James's recovery would be temporary only: 'I wouldn't be so sure that he's out of the woods yet'. ${ }^{87}$

Sargeson greatly admired Courage's work (though he had reservations regarding Courage's final two novels), and both men regularly exchanged missives as each acquired and then consumed the other's respective works. Despite their regard for one another, however, Brasch's correspondence with Sargeson reveals the very special tenor of intimacy that must have persisted between Brasch and Courage. Much like the letter quoted above, Brasch shared his views about Courage's well being with Sargeson, usually at the latter's request. While Sargeson's own correspondence with Courage was often unguarded - even frequently playful - it did not possess quite the same level of frankness as that of Courage and Brasch. ${ }^{88}$ Brasch, for example, was one of the first to hear of Courage's intention to write a homosexual novel (he had already published 'Guest at the Wedding' and 'Scusi' in Landfall). It was also Brasch that kept Sargeson - who apparently deemed it too indelicate to enquire himself - abreast of matters as the story ( $A$ Way of Love) moved towards completion. ${ }^{89}$

Brasch's correspondence with Sargeson underscores the degree of confidence that Courage must have felt for the Dunedin-based writer. Writing to Sargeson in March 1958 Brasch confirmed that Courage's latest project ('a homo one') had been accepted by Jonathan Cape (now an imprint of Random House) and that, while Cape was 'prepared for a hostile reception', they meant to secure a publisher in the United States. ${ }^{90}$ Somewhat ominously, Brasch wrote that Courage was 'alarmed' by thoughts of public scandal, and explained how he worried for his friend's psychological well-being. ${ }^{91}$ Writing again to Sargeson in December (with A Way of Love due to be published in Britain at any moment), Brasch spoke with considerable empathy of Courage's fragility:

No, Courage's book is to come out under his own name. He sounds very down, poor man; even last year I felt he was making a great effort in seeing me, even though he wanted to talk, wanted news, wanted friends to remember him; and I went away sad and somewhat frustrated each time, and felt that he shut the door behind me with immense if uneasy relief. I know the feeling so well though I never suffer it to that extent. $^{92}$

Courage's mental troubles worsened with age, and this tended to inhibit his social interactions. Certainly, as time passed, Courage saw his social intimates - literary or otherwise - individually or in smaller groups only. Even so, Courage continued to view his New Zealand literary friends as indispensible parts of his social and professional landscape, and he wrote with considerable anguish when mental and (sometimes) physical impositions meant he was unable to maintain these links as he would have liked. ${ }^{93}$

Brasch and Dowling remained the significant exceptions, and judging from Courage's own admissions, two of the few people allowed to understand the full context of his predicament. 'I don't love life any longer; it's too cruel and one is altogether too lonely in it', Courage wrote to Brasch in one pain-filled letter on the 12 July $1956 .{ }^{94}$ Courage stated his situation in the plainest and most abject of terms: he was 'terribly neurotic', suffered from a condition that was a part of his 'artistic gift', and hovered above the imminent collapse (the 'surface of chaos') only by virtue of psychiatric intervention. ${ }^{95}$ Courage gave still further detail later, adding that he suffered from 'a form of melancholic' 'psychoneurosis' that was in part 'narcissistic'. ${ }^{96} \mathrm{He}$ admitted to Brasch that he 'suffered almost all the time' since, even with the 'ruinous expense' of three weekly trips to the psychoanalyst, his condition still proved 'comparatively resistant to therapy'. ${ }^{97}$ However, here his friendship with Brasch took on increased significance. 'I seem, as so often when I 
write to you, to talk only of myself', Courage wrote to Brasch one afternoon in 1956. 'Your own voice comes through your letters strongly and confidently. You give me faith'. 98

\section{Conclusion}

This article underscores the connectedness of Courage's New Zealand associations. Clearly, these were durable relations. They were sustained across decades and a range of changing historical exigencies. Even so, these relationships were never static. An analysis of this material - as I suggest above - indicates Courage's increased intensification (at least as his mental health allowed) within New Zealand networks. This occurred as Courage grew older and his place within the metropolis solidified. The 1950s also show Courage at his most active within New Zealand's expatriate community. There may be both historical and personal explanations behind this shift. I have suggested, for example, how literary nationalism in the Antipodes motivated Courage's production of a consciously 'New Zealand' literature from London.

Courage's social connections clearly had more than professional significance, however. It is evident that Courage accrued a degree of satisfaction from his New Zealand associations (and his role as a lynchpin certainly would have afforded much social capital). In addition, these associations spoke very clearly to Courage own precise psychic needs. Courage's New Zealand friends played an increasingly integral part in his day-to-day and material welfare. Professional collegiality - not to mention shared class aspirations would have made these relationships particularly viable. Even so, a number of these social intimacies exceeded mere professional self-interest. Some - Brasch and the Dowlings especially - verged on the familial.

My analysis here is part of a much wider discussion about friendship and intimacy in my $\mathrm{PhD}$ thesis. In 'Speak to Me, Stranger: Subjectivity, Homosexuality and the Preliberation Narratives of James Courage', I argue that friendship for Courage was no mere standby for the supposedly more durable linkages of the family. Nor, as I suggest in my thesis, can friendship be easily separated from erotic and passionate encounter. By opening 'intimacy' to its widest ambit - to include, men, women, professional colleagues, and the like - we see how these relationships functioned within the experience of one individual's lifespan. Indeed, it cut across a slew of everyday social life, and formed a central vector for the production of Courage's own identity formation. ${ }^{99}$

What then of this later narrative of 'Courage as exile'? These stories emerge not during Courage's lifetime, but in memorials immediately after his death, and again under the changed political contexts in New Zealand from the 1980s. These narratives re-worked Courage's life into a compelling mythology, one that was built more upon cultural assumptions about New Zealand's 'puritanism' than the variegated and dynamic lives of individual preliberation lives. These stories mobilized the figure of James Courage as a means for proving the 'reality' of homophobia in the past, and the necessity for robust and compelling resistance in the present. In doing so, the trope of the Man Alone became central in purported 'truths' about Courage's life and the life of gay New Zealanders more generally. I have also suggested it to be the product of the strict gatekeeping of Courage's own life history: it is only very recently that we have gained access to his personal archive.

Deliberate misreading or selective reinterpretation, however, these stories remind us of the ongoing significance of certain narratives, and the intervention of changing cultural circumstances, in the way in which the contours of some lives are told and remembered. As an assumed reality, motifs like the Man Alone clearly have no explanatory power to describe the diverse subjective experiences of preliberation men. Taken as a narrative, however, or more specifically - a cultural metaphor - these re-workings remind us of 
history's place in the political landscape of recent memory. By studying this mythologizing in greater detail we can see how narratives about Courage contributed to a very specific moment in New Zealand's queer national imaginary. Perhaps more importantly, these same maneuvers also remind us of the importance of returning to the lived experience and voices - of those people we seek to understand.

${ }^{1}$ Phillip Wilson, 'James Courage: A Recollection', Landfall, 18, 3 (1964), pp.234-5.

${ }^{2}$ Ibid., p.234.

${ }^{3}$ Ibid.

${ }^{4}$ Ibid., p. 235 .

${ }^{5}$ Ibid., p. 235.

${ }^{6}$ Here I follow Sara Maza and others in their view of narratives not as 'inert containers' but as sources 'actively implicated' in historical and personal processes. Scholars like Kenneth Plummer have shown how stories inform 'the pathways to understanding culture' that shape questions of citizenship and notions of belonging. Others, Hayden White among them, argue convincingly for 'narrativity's close relationship' in generating notions of 'legitimacy' and in the production of real moral and social worlds. Taken broadly, this scholarship has looked to stories to explain how narratives mediate our perception of reality. These experts suggest that stories are key sites of memory and knowledge production. Far from simple accounts of real or fantastical events, narratives - as expressed in their myriad forms and variations - feed the cultural 'imaginaries' of nations and cultures. See Maza, 'Stories in History: Cultural Narratives in Recent Works of European History', American Historical Review, 101, 5 (1996), pp.1500-1; Plummer, 'Intimate Citizenship and the Culture of Sexual Story Telling', in Sexualities and Society: A Reader, Jeffrey Weeks, Janet Holland and Matthew Waites, eds. , Cambridge, 2003, p.33; Hayden White, The Content of the Form: Narrative Discourse and Historical Representation, Baltimore, 1987, p.14.

${ }^{7}$ For an explanation of these historical changes see Sean Brady, Masculinity and Male Homosexuality in Britain, 1861-1913, London, 2005, p.157; Richard Hornsey, The Spiv and the Architect: Unruly Life in Postwar London, Minneapolis and London, 2010, p.9; Chris Brickell, Mates and Lovers: A History of Gay New Zealand, Auckland, 2008, pp.256, 269.

${ }^{8}$ Joan W. Scott, 'Fantasy Echo: History and the Construction of Identity', Critical Inquiry, 27, 2 (2001), p.286.

${ }^{9}$ Matt Cook, London and the Culture of Homosexuality, 1885-1914, Cambridge, 2003, p.3.

${ }^{10} 23$ September 1920, James Courage Journal 1920-1924, MS-0999/078, Hocken Collections (HC), Dunedin.

11 Ibid.

12 Ibid.

13 Ibid.

${ }^{14}$ Lawrence Jones notes that there were three waves of New Zealand writing (and writers) in the first half of the twentieth-century. Courage does not appear in his list but, interestingly, would sit between the second (the 'central wave' that arrived in the 1930s and were associated with the Caxton Press) and third waves (authors who were active by the 1930s but whose careers were seriously interrupted by World War Two). Stuart Murray has likewise identified the 1930s as a pivotal moment in the building of a New Zealand literary culture but warns that this period has been 'over-mythologized' by writers and historians. He reminds us of the diversity of voices and perspectives that existed at the time, and he argues that New Zealand writing in the 1930s cannot be described as a 'linear journey to national selfhood'. See Jones, Picking Up The Traces: The Making of a New Zealand Literary Culture, 1932-1945, Wellington, 2003, p.16; Murray, Never A Soul at Home: New Zealand Literary Nationalism and the 1930s, Wellington, 1998, pp.11, 40.

154 September 1931, James Courage Journal 1929-1931, MS-0999/080, HC.

${ }^{16}$ James Courage to Charles Brasch, 7 November 1946, Brasch Papers, MS-0996-003/042, HC.

1715 October 1952, James Courage Journal 1950-1959, MS-0999/088, HC.

${ }^{18} 27$ March 1955, James Courage Journal 1950-1959, MS-0999/088, HC.

${ }^{19}$ Philip Steer, 'James Courage, 1903 - 1963', Kōtare, 7, 2 (2008), p. 227.

${ }^{20}$ N.W. Philpot to James Courage, 10 April 1959, Courage Papers, MS-0999/143, HC.

${ }^{21}$ Other critics derided Courage's ornamental ('sentimental') style, decrying a 'gentle primness' and 'refined femininity' sometimes evident in his work. Speaking of One House, for example, a reviewer for Tatler wrote that Courage's stories 'shouts a refined femininity'. See Author unknown, copy of book review from Tatler, 15 February 1933, Courage Papers, MS-0999/125, HC.

${ }^{22}$ For a more considered analysis of this approach, as well as how Courage's work sits alongside other preliberation contemporaries see Christopher Burke, 'Turning the Inside Out: Preliberation Literary Worlds in the Works of Frank Sargeson, Bill Pearson and James Courage', Journal of New Zealand Literature, 26 (2008), pp.95-118. 
${ }^{23} 12$ December 1962, James Courage Journal 1962-1963, MS-0999/091, HC.

${ }^{24}$ James Courage, A Way of Love, London, 1959, p.54.

${ }^{25}$ James Courage to Charles Brasch, 17 February 1959, Brasch Papers, MS-0996-003/042, HC.

${ }^{26}$ M.K. Joseph, for example, described the novel as a 'ruthless exposure of the pretensions of homosexuality, and a sad book, despite its appearance of an urbane and sensual exterior'. See Joseph's review, 'A Way of Love', Landfall, 13, 2 (1959), pp.178-9.

${ }^{27}$ John Lee, “'A Private History”: Towards a Biography of James Courage, Expatriate New Zealand Writer', MA thesis, Victoria University of Wellington, 2001, p.104.

${ }^{28}$ Arnold Wall to Kathleen Sheila Williams, 27 November 1986, MS-Papers-6138, Alexander Turnbull Library (ATL), Wellington.

${ }^{29}$ This was a rather unhappy end to a decade or more of near continual output for Courage. James had the opportunity to write just one final novel, the Freudian The Visit to Penmorten, before his death by heart failure in October of 1963. Rather crucially, the novel received an indifferent reception in both New Zealand and Britain. This seemed to confirm for Courage the end of his creative career. Embattled by mental and finally physical illness, any further literary enterprise seemed impossible. Courage does not record working further on anything of note. For discussions of this creative impasse see 13 December 1962, James Courage Journal 1962-1963, MS-0999/091, HC.

${ }^{30}$ Lawrence Jones, 'The Novel', in Terry Sturm, ed., The Oxford History of New Zealand Literature in English, Auckland, 1998, p.200.

${ }^{31}$ This recuperation has very much been a New Zealand-focused one. I have found no mention of Courage's work (or indeed his life) in British or American circles, either popular or academic. Still, Courage is mentioned in passing in Richard Hornsey's recent monograph on queer urban sexualities in London, suggesting his work may not have been entirely forgotten outside of New Zealand. See Hornsey, p.29.

32 'Introduction: Contested Pasts', in Katharine Hodgkin and Susannah Radstone, eds., Contested Pasts: The Politics of Memory, London and New York, 2003, p.5.

${ }^{33}$ Ibid.

${ }^{34}$ Ibid., p.1.

${ }^{35}$ Ibid., p. 16.

${ }^{36}$ Without refuting the importance of Oscar Wilde in many scripted experiences, some historians have been careful to assert that Wilde's own life and literature would not have had a solely determinative effect in and of itself. Matt Cook, for example, notes that Wilde's trial did not 'comprehensively stall the circulation of other [queer] ideas and explanatory narratives'. See Cook, p.119.

${ }^{37}$ Bobby Pickering, 'The Conspiracy Against James Courage', Pink Triangle, 18 (1980), p.5.

${ }^{38}$ Ibid.

${ }^{39}$ Ibid.

${ }^{40}$ Ibid.

${ }^{41}$ Ibid

${ }^{42}$ Ibid.

${ }^{43}$ David Young, 'Courage in Exile', New Zealand Listener, 101, 2211 (June 1982), p.24.

${ }^{44}$ Peter Wells, 'Introduction: Modest Achievements', in Peter Wells and Rex Pilgrim, eds., Best Mates: Gay Writing in Aotearoa New Zealand, Auckland, 1997, p.24.

${ }^{45}$ Ibid.

${ }^{46}$ Ibid.

${ }^{47}$ Ibid.

${ }^{48}$ Courage's editors were especially cautious in their dealings with him after the publication of The Young Have Secrets. While the precise nature of this dispute is unclear, letters to Charles Brasch from two of Courage's sisters stress how the 'surviving Wiggins daughter had been very angry' at some of the inferences made in the novel, and that she had been 'furious' upon the book's publication. See Constance Gray to Charles Brasch, undated, Brasch Papers, MS-0996-003/043, HC; Patricia Fanshawe to Charles Brasch, 29 July 1972, Brasch Papers, MS-0996-003/043, HC.

${ }^{49}$ Annamarie Jagose, Queer Theory: An Introduction, New York, 1996, pp.62, 69.

${ }^{50}$ Courage did not identify these men or explicate the nature of their intimacies at the time. However, in letters written to family members in New Zealand, D'Arcy Cresswell (speaking of his own relationship with Courage) mentions two New Zealanders by name said to have attended Oxford with Courage. These were John Harris and the writer Ormond Wilson. See 26 December 1940, James Courage Journal 1937-1940, MS0999/085, HC; D’Arcy Cresswell to Walter Cresswell, 19 July 1934, Cresswell Papers, MS-0170-005, ATL.

${ }^{51}$ Ephemera held at HC, include a large amount of assorted material from Courage's years at Oxford. These show a relatively active social life that included his participation with the dramatic society. Courage 
contributed at least two of his own plays. In addition, he was also an editor and frequent contributor to student magazine Isis.

5224 December 1940, James Courage Journal 1937-1940, MS-0999/085, HC.

${ }^{53}$ James Courage to Frederick Page, 17 April 1940, Page Papers, MS-3903-01/1/8, ATL.

${ }^{54}$ Ibid.

55 Ibid.

${ }^{56}$ Ibid.

${ }^{57}$ Ibid.

58 Ibid.

5927 July 1939, James Courage Journal 1937-1940, MS-0999/085, HC; James Courage to Charles Brasch, 22 March 1950, Brasch Papers, MS-0996-003/042, HC; James Courage to Charles Brasch, 29 September 1952, Dowling Papers, Misc-MS-0005, HC.

${ }^{60}$ James Courage to Charles Brasch, 18 August 1952, Brasch Papers, MS-0996-003/042, HC.

${ }^{61}$ Interestingly, with few exceptions, Courage never seems to have affiliated with Australians, despite the cultural and historical connections between the two countries.

${ }^{62}$ James Courage to Charles Brasch, 18 August 1952, Brasch Papers, MS-0996-003/042, HC.

${ }^{63}$ Ibid.

64 Ibid

${ }^{65}$ Courage was particularly miffed on this occasion, however. Bill Pearson had 'seized' the only copy of Landfall available at the gathering for the duration of that afternoon. See Ibid.

${ }^{66}$ James Courage to Charles Brasch, 12 August 1952, Brasch Papers, MS-0996-003/042, HC.

${ }^{67}$ Courage mentions meeting writer Phillip Wilson in this context. A 'long lanky chap with [a] faint American accent' (though he was New Zealand-born), Courage made his acquaintance with considerable enthusiasm, and subsequently followed his career with much evident interest. See James Courage to Charles Brasch, 18 August 1952, Brasch Papers, MS-0996-003/042, HC.

${ }^{68}$ For a more detailed explanation of social network theory see Stephen D. Berkowitz, An Introduction to Structural Analysis: The Network Approach to Social Research, Michigan, 1982; Mark Newman and Jason Watts, The Structure and Dynamics of Networks, Princeton, 2006.

${ }^{69}$ James Courage to Frederick Page, 17 April 1940, Page Papers, MS-3903-01/1/8, ATL.

${ }^{70}$ Ibid.

71 Ibid.

7215 December 1950, James Courage Journal 1950-1959, MS-0999/088, HC; 24 January 1963, James Courage Journal 1962-1963, MS-0999/091, HC.

${ }^{73}$ James Courage to Frederick Page, 14 April 1940, Page Papers, MS-3903-01/1/8, ATL.

${ }^{74}$ Ibid.

${ }^{75}$ James Courage to Charles Brasch, 12 August 1952, Brasch Papers, MS-0996-003/042, HC.

${ }^{76}$ James Courage to Rodney Kennedy, 22 February 1956, Kennedy Papers, Misc-MS-1284, HC.

${ }^{77}$ Ibid.

${ }^{78}$ Both Courage and Lilburn keenly felt their separation when, for example, the younger man left for New Zealand during the middle part of 1940. The pair had acquired a special intimacy during Lilburn's stay in London and, upon Lilburn's leaving England, Courage wrote with considerable dejection that '[o]ne hasn't all that number of friends that the absence of one makes no odds'. See 29 May 1940 James Courage Journal 1937-1940, MS-0999/085, HC.

${ }^{79}$ James Courage, The Young Have Secrets, London, 1954, Dedication.

${ }^{80}$ James Courage to Charles Brasch, 22 August 1963, Brasch Papers, MS-0996-003/042, HC.

8120 June 1960, James Courage Journal 1960-1961, MS-0999/089, HC.

8227 December 1962, James Courage Journal 1962-1963, MS-0999/091, HC.

${ }^{83}$ James Courage to Charles Brasch, 23 May 1961, Brasch Papers, MS-0996-003/042, HC.

${ }^{84}$ James Courage to Frederick Page, 19 April 1955, Page Papers, MS-3903-01/1/8, ATL.

${ }^{85}$ Ibid.

${ }^{86}$ Charles Brasch to Frank Sargeson, 24 September 1951, Sargeson Papers, MS-0432-147, ATL.

${ }^{87}$ Ibid.

${ }^{88}$ Indeed, when Courage's personal archive was deposited with the Hocken Collection, Dunedin, it seems that Brasch may have removed a number of his more revealing letters. Several that do remain contain notable incisions (the only of Courage's letters to bear any sign of censorship), and others are referred to by Courage in his correspondence and journal-writing but do not appear to have survived him.

${ }^{89}$ Charles Brasch to Frank Sargeson, 8 March 1958, Sargeson Papers, MS-0432-147, ATL.

${ }^{90}$ Ibid.

${ }^{91}$ Ibid. 
${ }_{93}$ Brasch to Sargeson, 15 December 1958, MS-0432-147, ATL.

${ }^{93}$ Speaking of Keith Sinclair's visit to London in 1951, for example, Courage wrote to Charles Brasch that he wished he felt 'well enough to see him' but that he shrank 'from contacts, whether I ought to or not'. See James Courage to Charles Brasch, 14 January 1951, Brasch Papers, MS-0996-003/042, HC.

${ }_{94}^{4}$ James Courage to Charles Brasch, 12 July 1956, Brasch Papers, MS-0996-003/042, HC.

95 Ibid.

${ }^{96}$ Courage to Brasch, 12 January, 1961, Brasch Papers, MS-0996-003/042, HC.

${ }^{97}$ Ibid.

98 James Courage to Charles Brasch, 12 July 1956, Brasch Papers, MS-0996-003/042, HC.

${ }^{99}$ For my discussion of this see Christopher Burke, 'Speak to Me, Stranger: Subjectivity, Homosexuality and the Preliberation Narratives of James Courage', PhD thesis, University of Otago, 2012, ch.6. 